\title{
Scleractinian Coral Communities of Two Inshore High Island Fringing Reefs at Magnetic Island, North Queensland
}

\author{
G. D. Bull \\ Department of Marine Biology, James Cook University, Townsville, 4811, Australia
}

\begin{abstract}
The characteristics of the scleractinian coral communities on 2 fringing reefs of an inshore high island were compared, using data from surveys by the line transect method. The communities are divided into zones on the basis of numbers of species per transect, species diversity indices, percentage coral cover and numerical classification of transects. The Geoffrey Bay community is divided into a Reef Flat Zone dominated by Goniastrea aspera, Platygyra sinensis and Montipora ramosa and a Reef Slope Zone dominated by arborescent and tabulate Acropora species. The Cockle Bay community is divided into an Inner Reef Flat Zone dominated by Montipora ramosa, an Outer Reef Flat Zone dominated by Platygyra sinensis and Symphyllia recta, and a Reef Slope Zone dominated by Goniopora tenuidens. Differences in community structure, species composition and distributions of abundant species of the zones of the 2 reefs, can be attributed to prevailing environmental conditions. In particular, differences in exposure to wave action and sedimentation between the reefs are reflected in smaller numbers of species, lower coral cover, lower values of the Shannon Diversity Index and selection of silt resistant species on the less exposed reef in Cockle Bay.
\end{abstract}

\section{INTRODUCTION}

This paper presents the first quantitatively based ecological study of coral assemblages on inshore fringing reefs in the Great Barrier Reef region. By virtue of their sheltered position and geomorphology these reefs are quite different from others described in the current literature.

Several quantitative coral community descriptions based on surveys by the line transect (or similar) method have been published. Most such descriptions of fringing reefs in the Indo-Pacific, e.g. Eilat (Loya and Slobodkin, 1971; Loya, 1972), Seychelles (Braithwaite, 1971), L'Ile Rodrigues (Faure and Montiaggioni, 1967), Réunion and Mauritius (Pichon, 1971) and Mahé, Sechelles (Rosen, 1971) show features determined by far greater exposure than is found at inshore areas such as Magnetic Island. Lovell (1975) has described shallow, sheltered coral assemblages in Moreton Bay (Southern Queensland), but recent coral growth there has not led to development of fringing reefs morphologically comparable with those described in the present study.

\section{THE STUDY AREA}

Magnetic Island is a high mainland island situated in Cleveland Bay approximately $8 \mathrm{~km}$ north of the City of Townsville (Fig. 1). Several of the island's bays have fringing coral reefs. The reefs chosen for this study are 2 of the most conspicuous: Cockle Bay Reef on the mainland (southwest) side of the Island and Geoffrey Bay Reef on the south east side. The reefs are formed by a thin (mostly $6 \mathrm{~m}$ or less), recently formed (since 6000 y B.P.) crust of reefal growth over large sand and mud banks (Hopley, 1982). The gradients of the outer reef slopes are extremely gentle; the reef front in Geoffrey Bay extends over a horizontal distance of $150 \mathrm{~m}$ with a maximum depth of $9 \mathrm{~m}$ (taken from $0 \mathrm{~m}$ tidal datum). In Cockle Bay the depth range is $4 \mathrm{~m}$ over a distance of $100 \mathrm{~m}$. The reef flat extends $150 \mathrm{~m}$ landward of the crest in Geoffrey Bay and $200 \mathrm{~m}$ in Cockle Bay. Both have extensive backreef sand/mud flats.

The island is well inshore in a relatively shallow, sheltered situation and comes under the freshwater and siltation influence of the mainland Ross and Burdekin Rivers. Rainfall in the area is seasonal with 


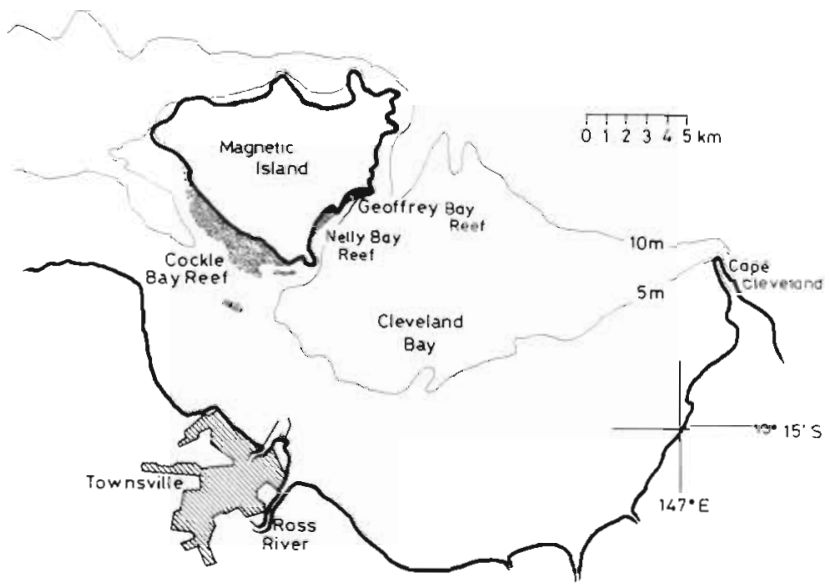

Fig. 1. Cleveland Bay area with Geoffrey Bay and Cockle Bay Reefs

approximately $70 \%$ of the annual fall on the Burdekin catchment occurring in the summer period, January to March (Pickard, 1977). Surface salinity and temperature measurements over $3 \mathrm{y}$ at an open water station in Cleveland Bay, between Magnetic Island and Cape Cleveland, showed a salinity range from $24.3 \%$ to $36.3 \% \mathrm{~S}$ and a temperature range from $19.3^{\circ}$ to $30.9{ }^{\circ} \mathrm{C}$ (Walker, 1981a, 1981b). However, there may be greater local variations in reef areas due to solar heating of shallow water and the influence of local island freshwater runoff. Collins (1978) recorded an extreme low salinity of $17.0 \% \mathrm{~S}$ after cyclonic rain, at a station on the reef flat in Nelly Bay (adjacent to Geoffrey Bay).

The prevailing winds entering Cleveland Bay are easterly or south easterly for most of the year and a west going swell is usually present. The Bay has a sandy-mud bottom composed of sand material eroded around headlands, silt and clay brought down by coastal rivers and locally some large particle size carbonate deposits from reef areas (Belperio, 1980). The wind and swell regime and the consequent distribution of terrigenous silt result in the Geoffrey Bay Reef, which is more exposed to swell, being less heavily silted than the Cockle Bay Reef. The tidal regime in the area is semi-diurnal with diurnal inequality. The mean tidal range during spring tide periods is $2.5 \mathrm{~m}$, and $0.8 \mathrm{~m}$ during neap tide periods (Dept. Harbours and Marine, 1976). As a consequence of the tidal range, the reef flat areas in Geoffrey and Cockle Bays are air-exposed for a few hours daily during spring tide periods, but not during neaps. The lowest daytime spring tides occur during winter (coolest and driest months)

\section{METHODS}

The procedures used for the line transect surveys were as described in detail by Loya (1972). The advan- tages of the line transect method for this kind of work are discussed by Loya (1978). A line length of $30 \mathrm{~m}$ was chosen by the species-number/transect-length method (Loya, 1972). The lines were positioned at right angles to a chosen line running from the beach edge to the reef front. Each transect was positioned so as to fall within one visually homogeneous area such that each major section of the reef (reef flat, reef crest and seaward slope) is represented by at least five transects (Fig. 2). By visually positioning transects in this way, the communities could be surveyed using fewer transect lines than would have been required if transects had been positioned at fixed intervals as has been the practice (Loya, 1972, etc.). Surveys of emersed reef flat areas were done during low spring tide, the remaining areas were surveyed using SCUBA.

Three samples of reef sediment were taken from each reef (Fig. 2) for analysis of grain size distribution using methods reviewed in Carver (1971).

Data were analysed using the James Cook University's PDP 10 computer. Formulae and notation for the Shannon diversity indices (Shannon and Weaver, 1948) are as used by Loya (1972). For cluster analysis of transects using the absolute cover values of all species present, the CLUSTAN 1C software package (Wishart, 1975) was employed with the Bray-Curtis Dissimilarity Index (as modified by Stephenson et al, 1970) and the Lance-Williams flexible fusion strategy (Lance and Williams, 1967) using the now standard value of beta $=-0.25$.

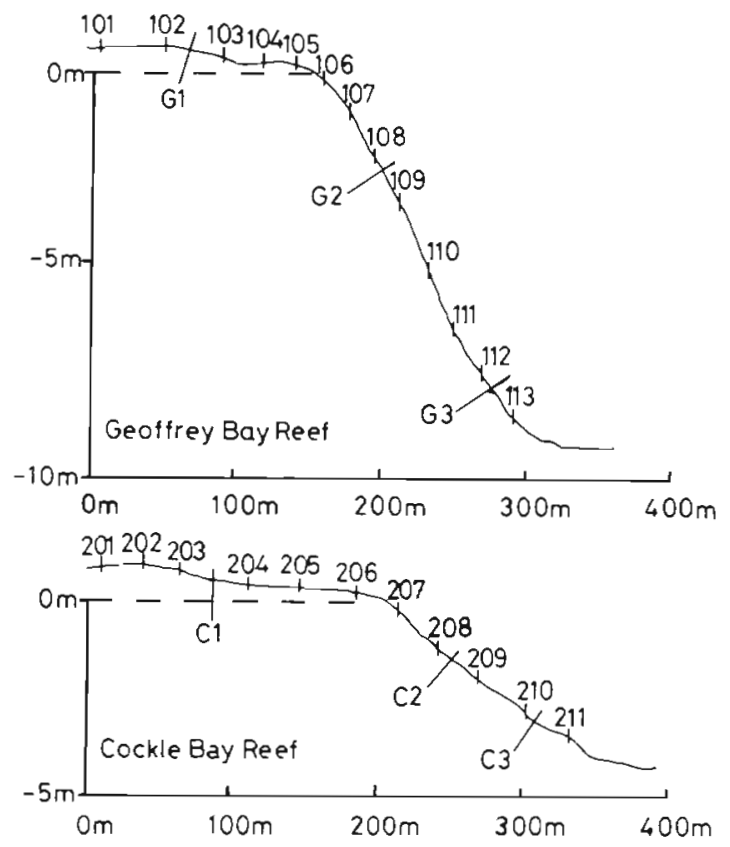

Fig. 2. Diagrammatic profiles of the 2 reefs showing positions of transect lines (101 to 113 and 201 to 211 ) and sediment sampling sites ( $\mathrm{Gl}$ to $\mathrm{G} 3$ and $\mathrm{Cl}$ to $\mathrm{C} 3$ ) 


\section{RESULTS}

\section{Sediment Grain Size Analysis}

The 2 reef flat samples are similar, except that the Cockle Bay reef flat sample (mean $p h i=1.54$ ) has slightly smaller mean grain size than the Geoffrey Bay reef flat sample (mean phi $=1.23$ ) which has an excess of coarse particles (-ve skewness). However, the subtidal samples from each reef differ greatly. The Cockle Bay slope samples have a much smaller mean grain size (mean phi $=3.34$ and 1.58 ), greater excess of fine particles and higher clay content $(7.8 \%$ and $4.1 \%$ ) than the Geoffrey Bay slope samples (mean phi $=0.75$ and 0.33 ; clay content $2.3 \%$ and $1.2 \%$ ). This reflects the reduced wave action and turbulence in Cockle Bay as compared with Geoffrey Bay.

\section{Species Composition and Distributions}

A total of 78 species belonging to 33 genera and 14 families were recorded during the line transect survey: 69 species in Geoffrey Bay and 42 species in Cockle Bay. Of these, 33 species were found on both reefs, 36 species were recorded only in Geoffrey Bay and 9 species were recorded only in Cockle Bay.

Abundant species on both reefs include Favia favus, Goniastrea aspera, Turbinaria mesenterina and Montipora ramosa. The number of species common to both reefs indicates some similarity between the communities. However, the following major differences in species composition and abundances between the reefs are apparent:

(1) A generally reduced complement of species is present in Cockle Bay as compared with Geoffrey Bay.

(2) Acropora species which are abundant on the Geoffrey Bay reef slope are almost totally absent from Cockle Bay.

(3) Other small polyped species - unlikely to be resistant to siltation - are present in Geoffrey Bay, but are rare in Cockle Bay, including Pachyseris speciosa, Oxypora lacera and various encrusting and foliose Montipora species.

(4) The reef slope in Cockle Bay is dominated by Goniopora tenuidens, a species able to resist siltation by having long, continually distended polyps. Another reason for the dominance of this species on the slope in Cockle Bay may be its ability to act as a primary coloniser of the soft substrate at the reef base by production of asexually reproduced 'polyp-balls' (Scheer, 1959, 1960; Rosen and Taylor, 1969). Other abundant species on the Cockle Bay reef slope include Symphyllia recta and Fungia fungites which, by their functional morphology, are likely to be active sediment rejectors (Hubbard and Pockock, 1972).

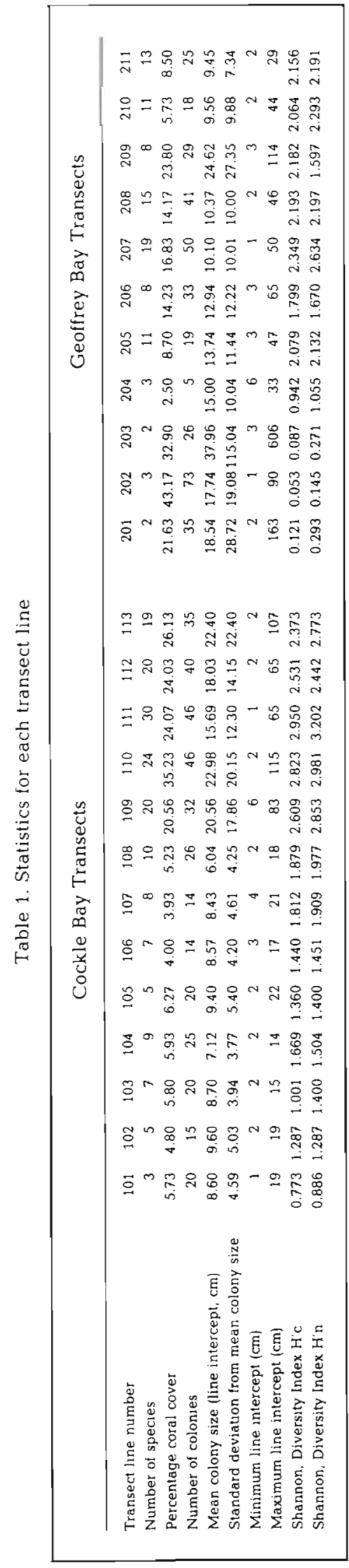




\section{Zonation}

Both reefs, from the lower limits of coral growth (the bases of the reef slopes) to the landward reef limits, can be regarded as single coral 'communities'. These can be divided into 'zones'. For the purpose of this study, zones are described as subdivisions of the coral communities which can be defined on the basis of percentage coral cover, colony size, number of species per transect and species diversity indices. Each zone has its own characteristic species composition, spatial distribution of species and dominant species.

The statistics calculated for each transect line (Table 1) and the results of cluster analysis (Fig. 3) indicate division of the Geoffrey Bay community into 2 zones: $A$, the Reef Flat and Crest Zone and B, the Reef Slope Zone. By contrast the Cockle Bay community is divided into: C, the Inner Reef Flat Zone; D, the Outer Reef Flat

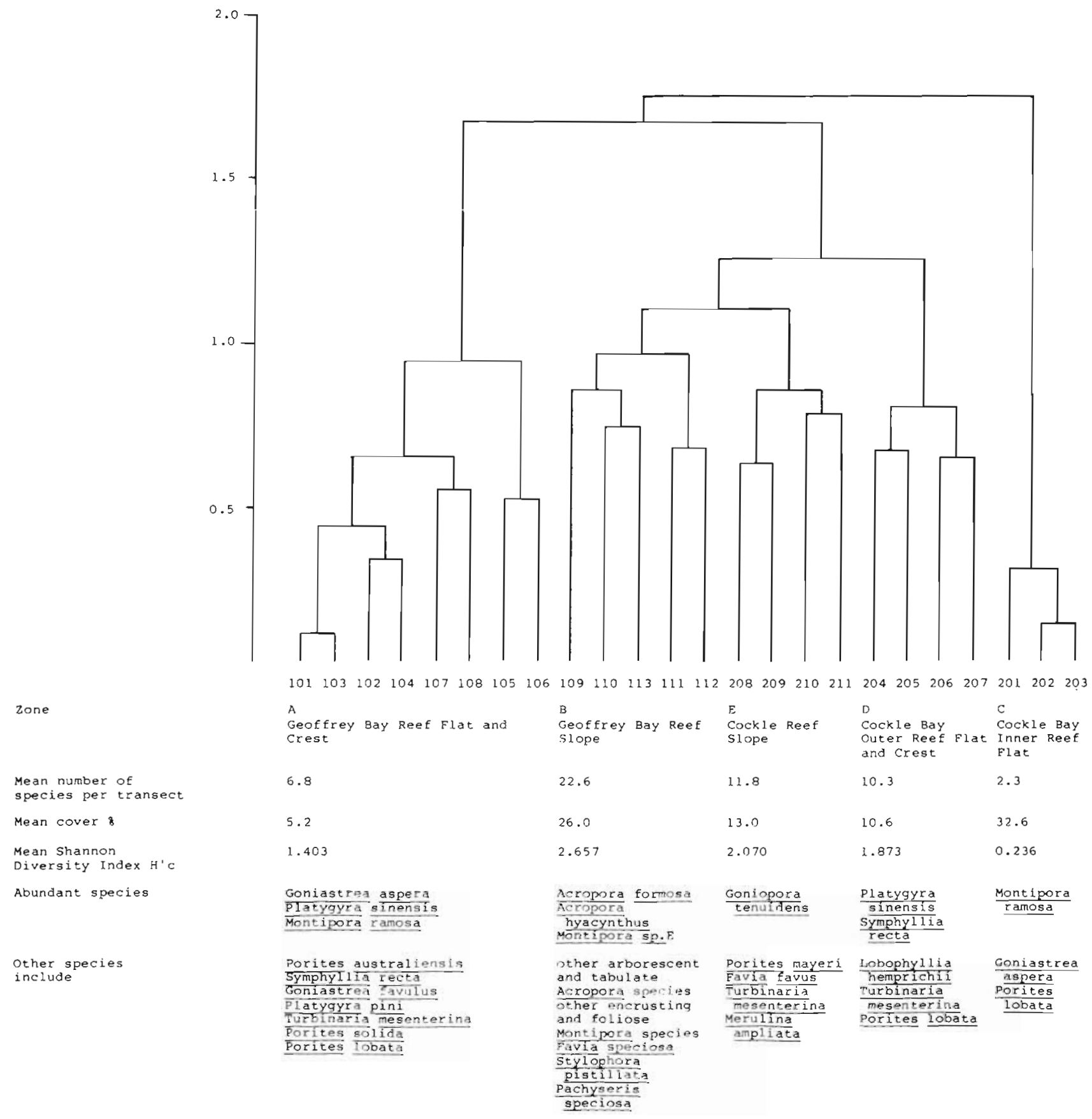

Fig. 3. Dendrogram from classification of transects with summarised characteristics of each zone 
and Crest Zone; and E, the Reef Slope Zone. The community structure parameters and species of each zone are summarised in Fig. 3.

\section{DISCUSSION}

There is an overall similartiy of species composition on the 2 reefs, shown in particular by the closeness of clustering of the 2 reef slope zones (B and E in Fig. 3). However, there are differences in dominant species and community structure parameters between the reefs.

The species complement is reduced in Cockle Bay, with associated lower numbers of species per transect and lower values of the Shannon Diversity Indices. There is also lower cover on the outer reef flat and slope of Cockle Bay and selection for siltation resistant species is apparent. This can be attributed to the higher sedimentation and finer sediment in Cockle Bay. These results are comparable with those of Loya (1976). Loya attributed similar differences in community structure between 2 sites at Puerto Rico to higher sedimentation and turbidity at one site.

In spite of the relatively sheltered position of Magnetic Island it is possible to compare the growth forms of the dominant coral species on the slope and outer reef flat zones with the synthetic models of Rosen (1971, 1975) and Pichon (1973). These models relate dominant coral growth forms to strength of water movement. In particular, the reef slope in Geoffrey Bay (Zone B) is dominated by arborescent and tabulate Acropora species. According to Rosen's and Pichon's models this is a reflection of moderate water movement. Conversely, the slope in Cockle Bay (Zone E) is dominated by the massive species Goniopora tenuidens. Similarly the outer flat and crest in Cockle Bay (Zone D) and the reef flat in Geoffrey Bay (Zone A) are dominated by massive species. These correspond to Rosen's Porites assemblage and Pichon's zone-type dominated by species with massive growth form, which is a reflection of reduced water movement.

The most abundant species on both reef flats is Montipora ramosa, which appears to be the only species able to maintain high cover on the reef flat areas with a shifting rubble substrate, probably because of a fast growth rate and ability to regenerate from fragments. The rubble substrate itself is largely composed of dead Montipora ramosa fragments. Other reef flat species only reach significant levels of cover and colony size where there is a firm substrate for attachment. Because Cockle Bay is very sheltered, the rubble is likely to be shifted rarely - only in severe storm or cyclonic surge conditions. This permits the development on the Cockle Bay inner reef flat of a zone totally dominated by Montipora ramosa, with high cover of that species. In Geoffrey Bay the rubble areas are much less extensive and less stable.

There are some similarities in zonation and species composition between this study and the descriptions of fringing reef flats at NW side of Maer Island, Murray Is. (Mayer, 1918), Gaua, New Hebrides (Baker, 1925), Bay of Batavia (Umbgrove, 1940) and Iwayama Bay, Palao (Abe, 1937). In particular, each of these studies includes a description of a Montipora ramosa zone comparable with the Inner Reef Flat Zone in Cockle Bay.

Acknowledgements. I wish to thank M. Pichon, J. Veron and C. Wallace for assistance with specimen identification. I am also thankful to Michel Pichon for his advice during the study and to Peter Arnold and Carden Wallace for their comments on the manuscript.

\section{LITERATURE CITED}

Abe, N. (1937). Ecological survey of Iwayama Bay, Palao. Trop. Biol. Stn. Stud. 1: 217-324

Baker, J. R. (1925). A coral reef in the New Hebrides. Proc. zool. Soc. Lond. 66: 1007-1009

Belperio, A. P. (1980). An inner shelf sedimentation model for the Townsville region, Great Barrier Reef Province, Ph.D. thesis, James Cook University of North Queensland, Townsville

Braithwaite, C. J. R. (1971). Seychelles reefs: structure and development. Symp. zool. Soc. Lond. 28: 39-63

Carver, R. E. (1971). Procedures in sediment petrology, WileyInterscience, New York

Collins, J. D. (1978). A study of the interactive biology of corals, Ph.D. thesis, James Cook University, Townsville

Department of Harbours and Marine, Queensland, Australia (1976). Official tide tables for Queensland with notes on boating, Government Printing Office, Brisbane

Faure, G., Montiaggioni, L. (1977). Les récifs coraliens auvent de L'Ile Maurice (Archipel des Mascareignes, Océan Indien): géomorphologie et bionomy de la pente externe. Mar. Geol. 21: M9-M16

Hopley, D. (1982). The geomorphology of the Great Barrier Reef, Wiley-Interscience, New York

Hubbard, J. A. E. B., Pockock, Y. P. (1972). Sediment rejection by recent scleractinian corals. Geol. Rundsch. 61: 599-626

Lance, G. N., Williams, W. T. (1967). A general theory of classificatory sorting strategies, I: Hierarchical systems. Comput. J. 9: 373-380

Lovell, E. R. (1975). The reef building corals (Coelenterata: Scleractinia) of Moreton Bay, Queensland: their distribution and ecology, M.Sc. thesis, University of Queensland, Brisbane

Loya, Y (1972). Community structure and species diversity of hermatypic corals at Eilat, Red Sea. Mar. Biol. 13: 100-123

Loya, Y. (1976). Effects of water turbidity and sedimentation on the community structure of Puerto Rican corals. Bull. mar. Sci. 26: 450-466

Loya, Y (1978). Plotless and transect methods. In: Stoddart, D R., Johannes R. E. (eds.) Coral reefs: research methods. U.N.E.S.C.O.

Loya, Y., Slobodkin, L. B. (1971). The coral reefs of Eilat (Gulf of Eilat, Red Sea). Symp. zool. Soc. Lond. 28: 117-139 
Mayer, A. G. (1918). Ecology of the Murray Island coral reef. Pap. Dep. Mar. Biol. Carnegie Inst. Wash. 9: 1-48

Pichon, M. (1971). Comparative study of the main features of some coral reefs of Madagascar, La Réunion and Mauritius. Symp. zool. Soc. Lond. 28: 185-216

Pichon, M. (1973). Recherche sur les peuplements à dominance d'anthozaires dans les récifs coralliens de Tuléar (Madagascar). Thèse Doct. ès. Sciences, Univ. Aix-Marseille 2

Pickard, G. L. (1977). A review of the physical oceanography of the Great Barrier Reef and western Coral Sea. Australian Institute of Marine Science Monograph Series 2

Rosen, B. R. (1971). Principal features of coral ecology in shallow water environments of Mahé, Seychelles. Symp. zool. Sac. Lond. 28: 163-183

Rosen, B. R. (1975). The distribution of reef corals. Rep. Underwater Ass. 1: 1-16

Rosen, B. R., Taylor, J. D. (1969). Reef coral from Aldabra: new mode of reproduction. Science, N. Y. 166: 119-121
Scheer, G. (1959). Die Formenvielfalt der Riffkorallen. Bericht 1958/1959 Naturwissenschaftlicher Verein Darmstadt 50: $50-67$

Scheer, G. (1960). Viviparie bei Steinkorallen. Naturwissenschaften $47: 238$

Shannon, C. E., Weaver, W. (1948). The mathematical theory of communication, Urbana, University of lllinois Press

Stephenson, W., Williams, W. T., Lance, G. N. (1970). The macrobenthos of Moreton Bay. Ecol. Monogr. 40: 459-494

Umbgrove, J. H. F. (1940). Madreporaria from the Bay of Batavia. Zool. Meded. 22: 1-64

Walker, T. A. (1981a). Seasonal salinity variations in Cleveland Bay, North Queensland. Aust. J. mar. Freshwater Res. 32: 143-149

Walker, T A. (1981b). The annual temperature cycle in Cleveland Bay, Great Barrier Province. Aust. J. mar. Freshwater Res. 32: 989-993

Wishart, D. (1975). Clustan IC user manual. Computer Centre, University College, University of London

This paper was presented by Dr. Y Loya; it was accepted for printing on September 10, 1981 